\title{
Climate analysis as a basis for a sustainable water management at the Lusatian Neisse
}

\author{
Thomas Pluntke
}

TU Dresden, Chair of Meteorology, PF 1117, 01735 Tharandt, Germany, e-mail: Thomas.Pluntke@tu-dresden.de

\author{
Susann Schwarzak \\ Bavarian Environment Agency, Unit Climate Change and Water Balance, Hof/Saale, Germany
}

Karin Kuhn, Kathleen Lünich

Saxon State Agency for Environment Agriculture and Geology, Germany

Mariusz Adynkiewicz-Piragas, Irena Otop, Bartłomiej Miszuk

Institute of Meteorology and Water Management - National Research Institute, Podleśna 61, 01-673 Warsaw, Poland, e-mail: mariusz.adynkiewicz-piragas@imgw.pl

\begin{abstract}
Current and future climate conditions and their impact on water balance, ecosystems, air quality and bioand agro-climatology were investigated in the region of the Lusatian Neisse within the two EU-projects - NEYMO and KLAPS. This work focuses on the climate analysis of the region at the German-Polish border as a preliminary step for a hydrological analysis of current and future conditions.

Observed climatological data were processed and analysed using the indicators air temperature, precipitation, sunshine duration, potential evapotranspiration and the climatic water balance (CWB). The latter defines the difference between precipitation and potential evapotranspiration and is a measure for the climatological water availability in the region. Observations were used to statistically downscale data from Global Circulation Models under various scenarios regarding greenhouse gas emissions (A1B, RCP 2.6, RCP 8.5) and applying the WETTREG-method for regionalization. In total, 50 climate projections for periods up until the end of the $21^{\text {st }}$ century were analysed, with the application of the mentioned indicators.

For the period 1971-2010, increasing trends of temperature, precipitation, sunshine duration and potential evapotranspiration were found. This leads to a reduced CWB in the summer half-year (SHY), which could be partly compensated by an increase in the winter half-year (WHY). Trends of temperature, sunshine duration and potential evapotranspiration remain positive for the far future (2071-2100), but precipitation decreases. These climatic conditions aggravate water availability, especially in the SHY. Impacts on water management are very probable and were therefore further investigated in the NEYMO project that applied hydrological models.
\end{abstract}

Key words: climate analysis, water availability, climate projections, trend analysis, Polish-Saxon border region

Submitted 8 June 2015, revised 10 July 2015, accepted 9 February 2016

\section{Introduction}

Transnational water management is a great challenge, especially under changing climate conditions. Within the expert group W1 of the Transboundary Water Commission, surface and groundwater related matters have been continuously coordinated between Poland and Germany since the year 1992. Natural water balance and water management are heavily affected by intensive open brown coal mining as well as by current and projected future climate change in the region of the Lusatian Neisse river catchment. The resulting hydrological changes and the need for a sustainable water management are among the main challenges in the Polish-Saxon border region. Within the EU-projects NEYMO - Lusatian Neisse/Nysa Łużycka climatic and hydrological modelling, analysis and projection $^{1}$ and KLAPS - climate change, air pollution and critical load of ecosystems in the Polish-Saxon border region ${ }^{2}$, current and possible future climate changes and their resulting impacts on hydrology, ecosystems, air quality and bio- and agro-climatology were investigated in the region of the Lusatian Neisse river catchment. Project partners are the Saxon State Agency for the Environment, Agriculture and Geology (lead partner), the Institute of Meteorol-

\footnotetext{
${ }^{1}$ http://www.umwelt.sachsen.de/umwelt/wasser/neymo

${ }^{2}$ http://www.klaps.sachsen.de
} 
ogy and Water Management - National Research Institute Wrocław Branch and the Department of Climatology and Atmosphere Protection at the University of Wrocław. Both projects were financed by the European Regional Development Fund (ERDF).

Only parts of the results of both mentioned projects are presented here. The paper focuses on current and projected future climate changes based on water management related indicators in the period 1971 to 2100 . They are calculated using observed as well as projected climate data. Special focus is given to the climatic water balance, which is defined as the difference between daily precipitation and potential evapotranspiration. The climatic water balance represents an effective indicator for characterizing wet and dry periods and therefore correlates well with hydrological conditions. The given results form a valuable basis for a first estimation of hydrologic conditions in the PolishSaxon border region. For further insight into hydrologic conditions and an improvement of the water management system, hydrologic modelling is required. Two different models were set up and calibrated for the Lusatian Neisse river catchment in the project NEYMO.

\section{Data and methods}

\subsection{Study area}

The study area is located in the south-western part of Poland and eastern Saxony, in Central Europe, with an extension of approximately $250 \times 180 \mathrm{~km}$ (Fig. 1). The orography is strongly influenced by plains in the northern part and various mid-range mountain areas (the Ore Mountains, Zittau Mountains, Izera Mountains, Giant Mountains) in the southern part of the project area. The highest peak is Śnieżka (in the Giant Mountains), which reaches $1.603 \mathrm{~m}$ a.s.l.

The project region is classified as a transition climate zone between maritime western European and continental eastern European climate within the west wind zone. However, the continental influence is dominant (SMUL 2005).

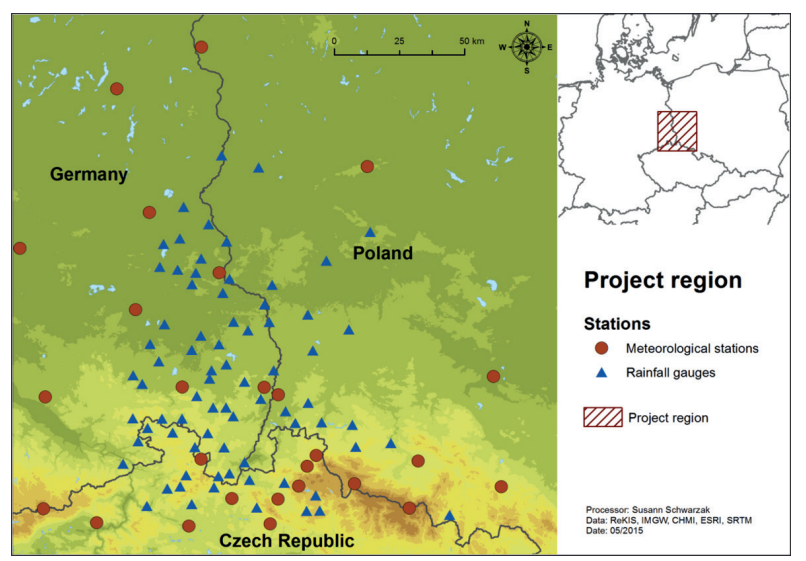

Fig. 1. Overview of topography and climate stations
Regional climate differences in the study area are primarily related to altitude and the influence of the southern mountain ranges. Affected by altitude, the average temperature during the summer half-year ranged for the period $1971-2000$ from $14.7^{\circ} \mathrm{C}$ in the Lowlands ( $<150 \mathrm{~m}$ a.s.1.) to $8.9^{\circ} \mathrm{C}$ on the Ridges $(>650 \mathrm{~m}$ a.s.1.). In the winter halfyear $3.3^{\circ} \mathrm{C}$ and $-1.7^{\circ} \mathrm{C}$ were reached, respectively. In the Sudety Mountains, the annual temperature decreases with increasing altitude, at a rate of $0.55^{\circ} \mathrm{C} / 100 \mathrm{~m}$ (Głowicki et al. 2005). Annual precipitation distribution is about 600 $\mathrm{mm}$ in the Lowlands and about $1.200 \mathrm{~mm}$ at the Ridges. Higher precipitation amounts are observed in the western part of the study area when compared to the eastern parts due to the main south-west wind direction, the resultant transport of maritime air masses and the shielding effect of the mountain ranges.

The land use is dominated by forestry (42\%) and agriculture $(42 \%)$ - the highlands are especially rich in forests (above $650 \mathrm{~m}$ a.s.l. spruce is dominant). The percentage of green land (8\%), urban areas $(6 \%)$ and water $(2 \%)$ is much lower (Mehler et al. 2014).

\subsection{Data}

The analysis of current climate change is based on a cross-border database of 26 observed daily climate stations and 100 rain gauge stations active from 1971 to 2010, provided by the German (DWD), Polish (IMGW-PIB) and Czech (CHMI) weather services (Fig. 1). As primary climatic elements, the mean, minimum and maximum air temperature, precipitation, sunshine duration, relative humidity and cloud cover were used. From these elements the secondary elements of global radiation and potential evapotranspiration were derived.

Observation data were tested for homogeneity and plausibility (Bernhofer, Franke 2013). Only homogeneous data series were used, and implausible values were treated as missing values. A data availability of at least $66 \%$ between 1971 and 2010 was defined as the threshold for data series to be considered in the analysis. Series passing this test were gap filled, with the following three steps applied: 1. Station internal gap filling of primary elements. Global radiation can be determined from cloud coverage (VDI 1994). Sunshine duration can be derived via global radiation by using the ÅNGSTRÖM approach (Ångström 1924).

2. Gap filling of primary elements like mean temperature, precipitation and sunshine duration by using the nearest three neighbouring stations and the inverse distance weighting interpolation method.

3 . Further station internal calculation of secondary elements like global radiation (Ångström 1924) and po- 
tential evapotranspiration (Turc-Wendling approach: ATV-DVWK 1996), which is possible for the currently filled time steps.

Regional climate projections for the period 1971-2100 were developed. Depending on several socio-economic and ecological characteristics, there is a need for climate scenarios to model possible future climate conditions. Therefore, so called Representative Concentration Pathway (RCP) scenarios which were provided with the $5^{\text {th }}$ assessment report of the Intergovernmental Panel on Climate Change (IPCC 2013) are applied. Oriented on the "2-degree-target", the RCP 2.6 scenario (490 ppm $\mathrm{CO}_{2}$ -equivalent) represents a global warming which does not reach the level of $2{ }^{\circ} \mathrm{C}$ at the end of the $21^{\text {st }}$ century when compared to the preindustrial level. An approximately three times higher primary energy consumption of 1370 ppm $\mathrm{CO}_{2}$-equivalent is assumed under the RCP 8.5 scenario (Randalls 2010). Within previous IPCC reports, so-called Special Report on Emission Scenarios (SRES) was established (Nakicenovic, Swart 2000). To establish the link to studies of the recent years, the SRES A1B is additionally used. Data from the global circulation model (GCM) MPI-ESM-LR and its former version ECHAM5 were used as input for the statistical downscaling method WETTREG2013 (Kreienkamp et al. 2013; Fig. 2). This method establishes statistical relationships between atmospheric variables (re-analysis data or data modelled by the GCM) and climatic observations at the existing stations for the period 1971-2000. Applying these relationships, ten possible realizations - as a result of a stochastic weather generator - of the concrete climatological consequences of projected atmospheric conditions at the stations are obtained for the period 2011-2100. Altogether, 50 realizations were obtained. The quantity of realizations was limited to ten for all five GCMs, according to the recommendations of the developers of WETTREG2013.

The multi-scenario approach was used to estimate the possible bandwidth of future climate conditions and to reduce uncertainties. Furthermore, internal model variability of the MPI-ESM-LR global model was considered by applying three runs of the RCP 8.5 scenario. The internal model variability of WETTREG2013 is accounted for considering ten realizations.
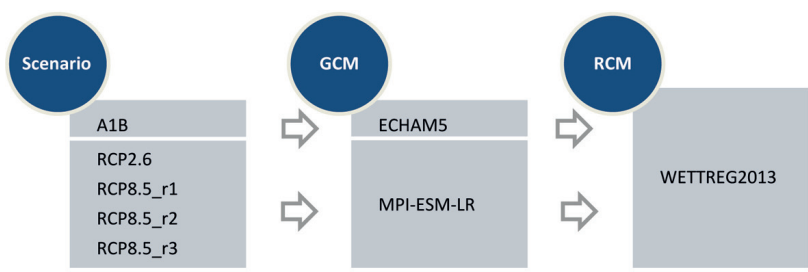

Fig. 2. Applied scenarios and Global Circulation Models for regional climate modelling
Projections with WETTREG2013 were validated by comparing observed and simulated values for the period 1971-2000. For ECHAM5-A1B and MPI-ESM-LR run1, the model performs very well for temperature $\left( \pm 0.3^{\circ} \mathrm{C}\right)$, well for precipitation $( \pm 5 \%$, in winter $\pm 10 \%)$ and well for sunshine duration ( \pm 0.2 hours). The performance of the WETTREG method proved to be comparable to RCMs (Jacob 2007).

\subsection{Methods}

Among the multitude of indicators which characterize climatic conditions in a region, we chose indicators with mid- and long-term impacts on water management. This study focuses on the climatic water balance (CWB), which is why the mean temperature (TM), precipitation (RR), sunshine duration (SD) and potential evapotranspiration (ETP) were also assessed (Table 1). The CWB is a well suited measure of the water availability in the region from a climatic point of view, because it considers not only the input (RR), but also the losses (ETP) of the system. Negative values indicate water shortage and positive values indicate water excess. In reality, water balance is determined by water flows above and through the ground, by water transport via plants etc. These processes are normally simulated with (e.g. hydrological) models.

Observed long-term climate changes (minimum 30 years) are quantified by a linear trend analysis for the period 1971-2010. The absolute trend $T_{a b s}$ is calculated as the difference between the end value and the first value of the regression line. The relative trend $T_{r e l}$ is given as the quotient of $T_{a b s}$ and the arithmetic mean of the value of interest. To check the trend for statistical significance a nonparametric test after Mann (1945) and Kendall (1976) was applied. Trend maps in chapter 3.1 illustrate trend direction $($ positive $=$ red triangle; negative $=$ blue triangle), strength of the trend (triangle size), and significance (black dot within triangle) for the analysed climate indices. The statistical significance level is defined as $10 \%$ in this study.

Table 1. Selected indicators

\begin{tabular}{|c|c|l|}
\hline Abbreviation & Unit & \multicolumn{1}{|c|}{ Description } \\
\hline TM & ${ }^{\circ} \mathrm{C}$ & Daily average temperature \\
\hline RR & $\mathrm{mm}$ & Daily precipitation total \\
\hline SD & hours & Sum of daily sunshine hours \\
\hline ETP & $\mathrm{mm}$ & $\begin{array}{l}\text { Potential evapotranspiration of the atmos- } \\
\text { phere. Calculated with the TURC-WEND- } \\
\text { LING approach (ATV-DVWK 1996) using } \\
\text { global radiation and mean temperature }\end{array}$ \\
\hline CWB & $\mathrm{mm}$ & $\begin{array}{l}\text { Difference between daily precipitation and } \\
\text { potential evapotranspiration. }\end{array}$ \\
\hline
\end{tabular}


Possible future climate changes are represented as climate change signals for the two target periods: 2021-2050 (near future - NF) and 2071-2100 (far future - FF). To overcome problems of the model's inherent bias, these signals are calculated as differences between modelled future climates and the modelled climate of the reference period 1971-2000. Additionally, a confidence interval is calculated to distinguish between a significant climate change signal and natural climate variability (Taubenheim 1969). The confidence interval $V B$ is calculated using the mean $\bar{x}$ and standard deviation $s d$ of the reference period 19712000:

$$
V B=\bar{x} \pm t_{\beta}(n) \cdot \frac{s d}{\sqrt{N}}
$$

where: $N$ - amount of values; $n$ - degree of freedom; $\beta$ - error probability, $\beta=0.01 ; t-$ students' test statistics, $t=2.75$.

To estimate regional as well as seasonal differences, climate analysis was performed using suitable elevation levels (Table 2) and two seasons of the year: summer-half-year (SHY, from April until September) and winter-half-year (WHY, from October until March).

Table 2. Classification of elevation levels

\begin{tabular}{|c|c|}
\hline Elevation level & Altitude [m a.s.l.] \\
\hline Lowland & $\leq 150$ \\
\hline Hillside & $151-350$ \\
\hline Mountain range & $351-650$ \\
\hline Ridges & $>650$ \\
\hline
\end{tabular}

\section{Results}

\subsection{Current climate}

The mean temperature shows a pronounced height gradient with a mean annual temperature of $0.7^{\circ} \mathrm{C}$ at Śnieżka Mtn. and $9.3^{\circ} \mathrm{C}$ in Cottbus. This characteristic is recognizable in the two investigated seasons throughout all four elevation levels (Table 3). All stations display positive trends, where absolute trends are highest at the Ridges. Except for one station, trends are significant for the year (Fig. 3) and the SHY, but not for the WHY. With an increase between $1.8^{\circ} \mathrm{C}$ and $2.0^{\circ} \mathrm{C}$ within 40 years, the changes in temperature can be considered drastic during the SHY. Analysis of all four seasons (not shown here) reveals the reason for lower trends in WHY: especially in winter, the trends are small and for many stations are even negative.

Annual precipitation totals range from $608 \mathrm{~mm}$ in the Lowlands up to $1200 \mathrm{~mm}$ at the Ridges (Table 3). The highest values were recorded in the Izera Mountains (Jakuszyce: $1371 \mathrm{~mm}$ ) and the lowest in the Lusatian-Silesian Lowland (Legnica: $515 \mathrm{~mm}$ ). Once again, a significant height gradient exists. The increasing influence of continental weather patterns onto climate in the study area illustrates a comparison with the neighbouring German state Saxony - annual precipitation amounts of $643 \mathrm{~mm}$ in the study area are about $70 \mathrm{~mm}$ less than in Saxony. Precipitation is about $37 \%$ higher in the Lowlands and Hillsides in the SHY than in the WHY. In the Highlands and Ridges the difference is lower (18\%). In all seasons and at all elevation levels, except the Ridges in the SHY, a positive tendency of precipitation was found. But, also on other elevation levels, there are stations that contradict the general positive trend (Fig. 3). Only a few stations show significant trends for the year, but this share is much higher in the WHY.

Sunshine duration amounts to 1650 hours per year in the Lowlands, but progressively less at higher altitudes (Table 3). The main reason here is the orographically induced cloud formation. In the last 40 years, sunshine duration has increased (mostly) significantly Fig. 3, and so the trend signal is clear for the SHY but ambiguous for the WHY.

The potential evapotranspiration (ETP) of $661 \mathrm{~mm}$ per year in the Lowlands is higher than precipitation in the same region. Decreasing temperatures at higher altitudes lead to reduced ETP, e.g. $518 \mathrm{~mm}$ at the Ridges (Table 3). As mean temperature and sunshine duration are used for the estimation of ETP here, the increasing trends of ETP are consequential. Annual trends and trends for the SHY are significant (Fig. 3).

The Climatic Water Balance (CWB) joins all described climatic variables into one indicator (Table 3). In Fig. 4, the four elevation levels are merged into two levels, because only a few stations dispose of all required variables. Furthermore, the two levels facilitate comprehensibility, especially in chapter 3.1. On an annual basis, the CWB is negative in the Lowlands, balanced in the Hillsides and strongly positive at the Ridges. This results from the positive height gradient of precipitation and the negative gradient of ETP. From a climatological point of view, the Lowlands are a water deficit region and it is only at higher altitudes that water exists in excess. Water deficit is very pronounced during the SHY, and only the Ridges exhibit water excess. In the WHY, water input exceeds the water losses in the whole region. Fig. 4 illustrates the opposing trends and the resulting problems during the half years. In regions lower than $350 \mathrm{~m}$ a.s.l., CWB is negative in the SHY. An absolute trend of $-53 \mathrm{~mm}$ in the last 40 years indicates an aggravation of the water deficit. At the Ridges, the trend is even more pronounced $(-159 \mathrm{~mm})$, but as sufficient water is available it doesn't pose a problem yet. In the WHY a positive trend of precipitation dominates the also positive trend of ETP, so the CWB also results in a positive trend. 
Table 3. Calculated indices (1971-2000) and its absolute trends (1971-2010) for the whole year, the summer half-year and winter half-year for four elevation levels; for units see Table 1; red and blue indicate positive and negative trends, respectively

\begin{tabular}{|l|c|c|c|c|c|c|c|c|c|}
\hline & & \multicolumn{2}{|c|}{ Lowlands } & \multicolumn{2}{c|}{ Hillsides } & \multicolumn{2}{|c|}{ Highlands } & \multicolumn{2}{|c|}{ Ridges } \\
\hline Index & Season & Mean & Trend & Mean & Trend & Mean & Trend & Mean & Trend \\
\hline Precipitation & Year & 608 & 75 & 701 & 73 & 861 & 102 & 1183 & 27 \\
\hline Precipitation & SHY & 350 & 31 & 406 & 26 & 471 & 42 & 634 & -21 \\
\hline Precipitation & WHY & 258 & 31 & 295 & 38 & 390 & 52 & 548 & 45 \\
\hline Mean Temperature & Year & 9.0 & 1.2 & 8.4 & 1.0 & 7.8 & 1.1 & 3.6 & 1.2 \\
\hline Mean Temperature & SHY & 14.7 & 1.9 & 14.1 & 1.8 & 13.4 & 1.9 & 8.9 & 2.0 \\
\hline Mean Temperature & WHY & 3.3 & 0.6 & 2.6 & 0.3 & 2.1 & 0.3 & -1.7 & 0.6 \\
\hline Sunshine Duration & Year & 1653 & 246 & 1508 & 280 & 1428 & 267 & 1377 & 215 \\
\hline Sunshine Duration & SHY & 1191 & 208 & 1074 & 245 & 1032 & 263 & 951 & 211 \\
\hline Sunshine Duration & WHY & 461 & 43 & 434 & 33 & 397 & 0 & 427 & 2 \\
\hline Potential Evapotranspiration & Year & 661 & 69 & 635 & 76 & & & 518 & 62 \\
\hline Potential Evapotranspiration & SHY & 527 & 65 & 501 & 74 & \multicolumn{2}{|c|}{ no data } & 409 & 62 \\
\hline Potential Evapotranspiration & WHY & 135 & 3 & 134 & 1 & & & 110 & -1 \\
\hline Climatic Water Balance & Year & -116 & -26 & 8 & -38 & & & 543 & -81 \\
\hline Climatic Water Balance & SHY & -194 & -52 & -111 & -53 & no data & 172 & -159 \\
\hline Climatic Water Balance & WHY & 78 & 14 & 118 & 6 & & & 371 & 78 \\
\hline
\end{tabular}

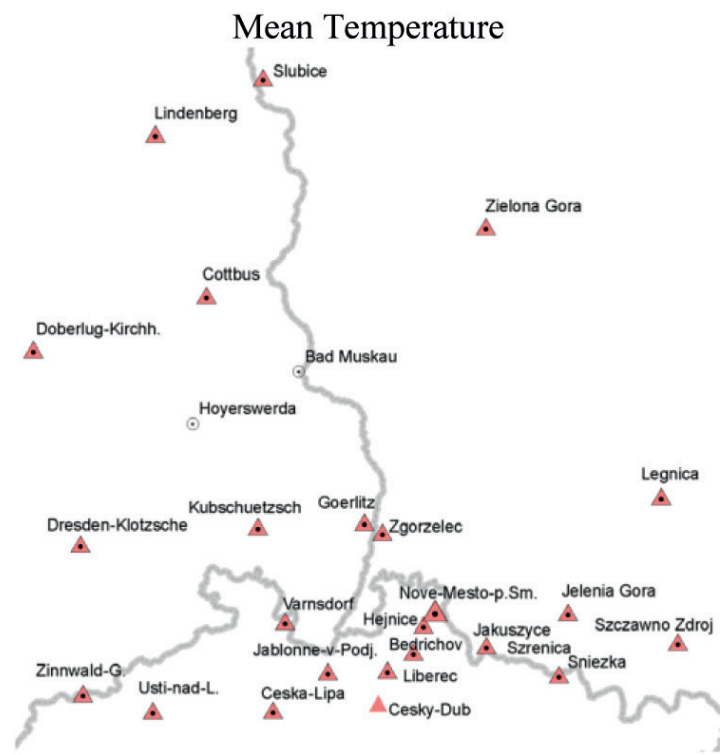

Potential Evapotranspiration

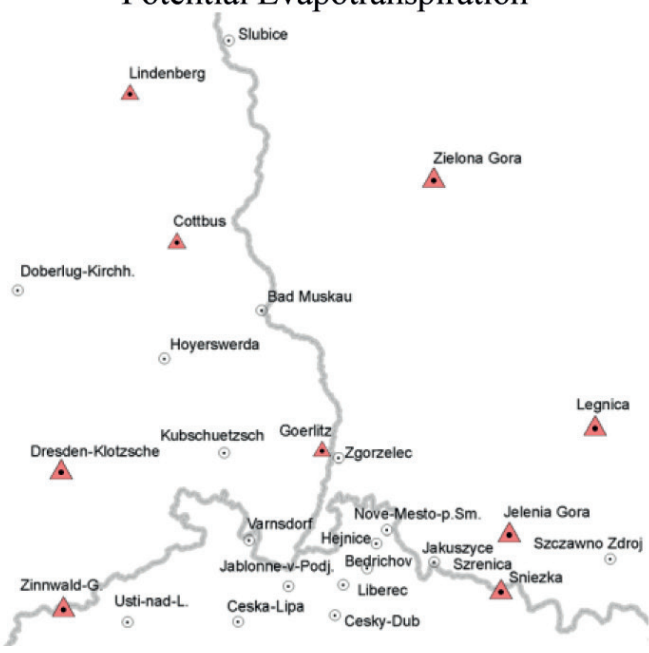

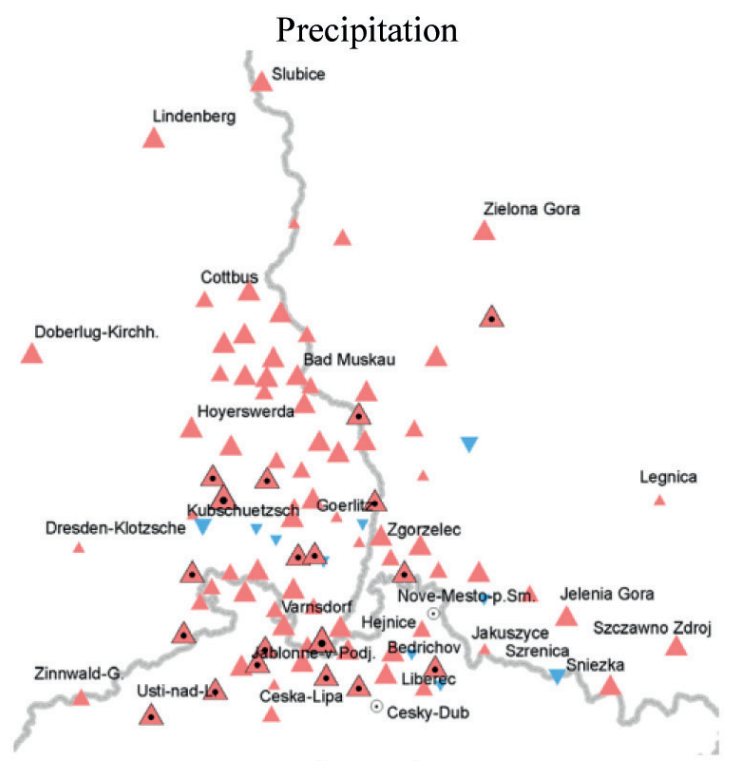

Legend

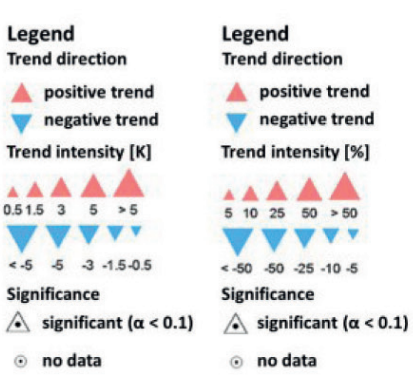

Fig. 3. Trends of annual values of three indices for the period 1971-2010; legend: left for temperature, right for other indices 


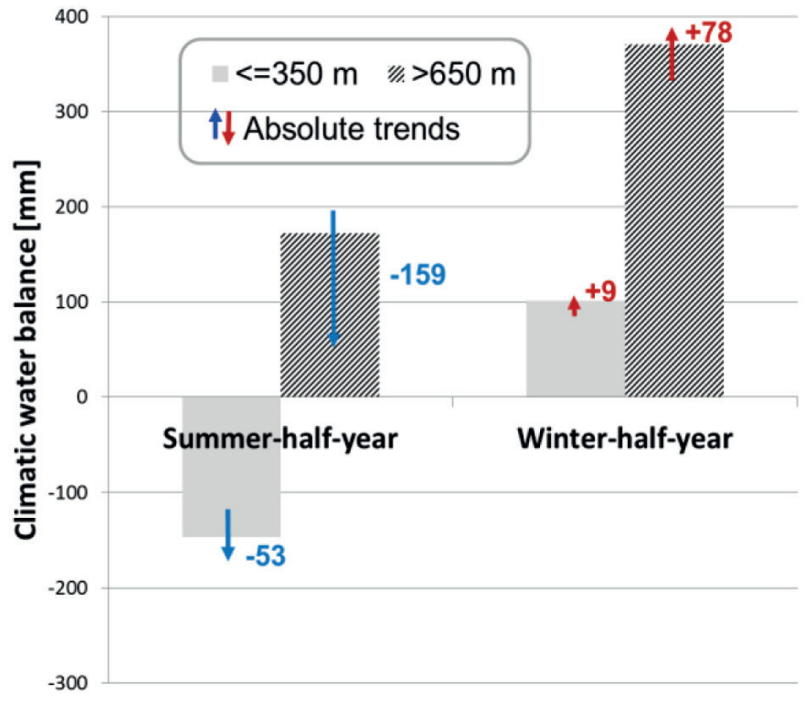

Fig. 4. Climatic water balance of the reference period 1971-2000 and absolute trends (1971-2010) for winter and summer halfyear for two elevation levels

\subsection{Projected climatic conditions}

Reference to, e.g., the A1B scenario includes in the following full set (or the mean of ten) of WETTREG2013 realizations which had the GCM with the mentioned scenario as a driving model. All climate change signals of the investigated indices are listed for four elevation levels and for two periods in the $21^{\text {st }}$ century (in Table 4). Graphically displayed are TM, RR and ETP (in Fig. 5) and CWB (in Fig. 6). A climate change signal is significant when the climate element exits the confidence interval, i.e. the signal is outside the range of natural variability (see Fig. 5).

Simulations of the temperature reveal a significant temperature increase, which is moderate for RCP $2.6\left(1{ }^{\circ} \mathrm{C}\right)$ and substantial for RCP 8.5 and A1B $\left(3.1-3.6^{\circ} \mathrm{C}\right)$ until 2100. Changes do not differ significantly between the SHY and WHY. There is a slightly increasing trend of climate change signals with elevation, i.e. higher elevated regions are more affected by temperature increase.

Yearly precipitation totals do not show uniform changes. Negative changes prevail in the SHY (up to $-119 \mathrm{~mm}$ for RCP 8.5) and positive changes prevail in the WHY, whereby changes in the NF are much smaller than in the FF. RCP 2.6 depicts a scenario with relatively small changes, with even slight precipitation benefits. Regions of higher elevations are most affected; they profit less from the increase during the WHY but suffer most from the reductions during the SHY. Although RCP 8.5 and A1B show a similar behaviour, the former produces even drier conditions. Fig. 5 illustrates the high variability between the ten realizations of a scenario in comparison to temperature. It should be noted that all realizations have the same occurrence probability.

Sunshine duration increases in all elevation levels, all seasons and all (except RCP 2.6 during the WHY) scenarios in the $21^{\text {st }}$ century. Increases are more pronounced in the FF, with a bandwidth from only 44 hours in the Lowlands for RCP 2.6, up to 345 hours at the Ridges for A1B. In general, higher altitudes are more affected by the positive changes than lower regions.

The signal of potential evapotranspiration follows their determining variables temperature and global radiation (derived from sunshine duration), i.e. it increases in all seasons, all elevation levels and all scenarios. Lowest changes feature RCP 2.6 and highest changes RCP 8.5. Lowlands and Hillsides are - despite their slightly smaller signals in tem-

\begin{tabular}{|c|c|c|c|c|c|c|c|c|c|c|c|c|c|c|c|c|c|c|c|c|c|}
\hline \multirow[b]{2}{*}{ Sceanrio } & \multirow[b]{2}{*}{ Period } & \multicolumn{4}{|c|}{ Precipitation } & \multicolumn{4}{|c|}{ Mean Te mpe rature } & \multicolumn{4}{|c|}{ Sunshine Duration } & \multicolumn{4}{|c|}{ Potential Evapotrans pirat. } & \multicolumn{4}{|c|}{ Climatic Water Balance } \\
\hline & & Low. & Hill. & Moun. & Ridg. & Low. & Hill. & Moun. & Ridg. & Low. & Hill. & Moun. & Ridg. & Low. & Hill. & Moun. & Ridg. & Low. & Hill. & Moun. & Ridg. \\
\hline Year & & & & & & & & & & & & & & & & \multirow{7}{*}{$\begin{array}{l}\text { 蹗 } \\
\text { \& }\end{array}$} & & & & \multirow{7}{*}{ 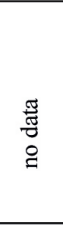 } & \\
\hline A1B & NF & 7 & 0 & -9 & -23 & 1.3 & 1.3 & 1.3 & 1.3 & 120 & 130 & 139 & 138 & 41 & 43 & & 38 & -44 & -43 & & -51 \\
\hline A1B & FF & -2 & -43 & -62 & -104 & 3.2 & 3.2 & 3. & 3.3 & 285 & 333 & 344 & 345 & 100 & 108 & & 95 & -116 & -144 & & -188 \\
\hline CP 2.6 & NF & 17 & 4 & -4 & -4 & 1.0 & 1.1 & 1.1 & 1.1 & 53 & 66 & 76 & 56 & 25 & 28 & & 23 & -14 & -24 & & -14 \\
\hline CP 2.6 & FF & 11 & -5 & -12 & -22 & 1.0 & 1.0 & 1.0 & 1.0 & 44 & 57 & 69 & 58 & 24 & 26 & & 23 & -16 & -29 & & -39 \\
\hline RCP 8.5 & NF & 7 & -10 & -25 & -36 & 1.5 & 1.5 & 1.6 & 1.6 & 147 & 162 & 169 & 180 & 51 & 53 & & 48 & -48 & -64 & & -67 \\
\hline RCP 8 & & 4 & -40 & -66 & -117 & 3.5 & & & 3.6 & 267 & 301 & & 337 & 101 & 107 & & 98 & -105 & -144 & & -203 \\
\hline \multicolumn{22}{|l|}{ SHY } \\
\hline A1B & $\mathbf{N F}$ & -1 & -6 & -13 & -28 & 1.2 & 1.2 & 1.2 & 1.3 & 93 & 104 & 119 & 114 & 33 & 35 & \multirow{6}{*}{$\begin{array}{l}\text { 急 } \\
\text { 号 }\end{array}$} & 31 & -45 & -43 & \multirow{6}{*}{$\begin{array}{l}\text { 超 } \\
\text { ̊ }\end{array}$} & -48 \\
\hline A1 & FF & -26 & -57 & -73 & -116 & 2.9 & 3.0 & 3.0 & 3.1 & 220 & 262 & 286 & 275 & 80 & 87 & & 77 & -122 & -142 & & -173 \\
\hline RCP 2.6 & NF & 10 & 2 & -2 & -2 & 0.9 & 1.0 & 1.0 & 1.1 & 51 & 64 & 76 & 63 & 21 & 23 & & 19 & -16 & -22 & & -8 \\
\hline RCP 2.6 & FF & 3 & -10 & -17 & -26 & 0.9 & 0.9 & 1.0 & 1.0 & 49 & 61 & 71 & 65 & 20 & 22 & & 20 & -21 & -32 & & -37 \\
\hline RCP 8.5 & NF & 2 & -13 & -26 & -40 & 1.5 & 1.6 & 1.6 & 1.7 & 123 & 139 & 151 & 153 & 42 & 45 & & 40 & -46 & -60 & & -61 \\
\hline RCP 8.5 & FF & -13 & -47 & -70 & -119 & 3.4 & 3.5 & 3.6 & 3.6 & 205 & 240 & 255 & 265 & 81 & 87 & & 79 & -103 & -136 & & -178 \\
\hline \multicolumn{22}{|l|}{ WHY } \\
\hline & $\mathrm{NF}$ & 8 & 5 & 2 & 4 & 1.4 & & & 1.3 & 2 & 2 & & 22 & & 0 & \multirow{6}{*}{ 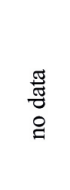 } & 6 & & 0 & \multirow{6}{*}{ 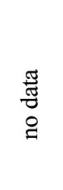 } & -5 \\
\hline A1B & FF & 26 & 16 & 13 & 15 & 3.5 & 3.5 & 3.5 & 3.4 & 63 & 69 & 55 & 67 & 20 & 21 & & 18 & 7 & 1 & & -12 \\
\hline RCP 2.6 & NF & 7 & 3 & 0 & 0 & 1.2 & 1.2 & 1.2 & 1.2 & 1 & 3 & -1 & -9 & 5 & 5 & & 3 & 2 & -1 & & -4 \\
\hline RCP 2.6 & FF & 8 & 5 & 5 & 4 & 1.1 & 1.1 & 1.1 & 1.1 & -6 & -4 & -2 & -8 & 4 & 4 & & 3 & 5 & 3 & & -2 \\
\hline RCP 8.5 & NF & 5 & 3 & 1 & 5 & 1.5 & 1.5 & 1.5 & 1.5 & 22 & 22 & 16 & 25 & 8 & 8 & & 7 & -2 & -5 & & -5 \\
\hline RCP 8.5 & FF & 19 & 8 & 5 & 4 & 3.6 & 3.5 & 3.5 & 3.5 & 60 & 59 & 44 & 69 & 20 & 20 & & 18 & -1 & -7 & & -23 \\
\hline
\end{tabular}

Table 4. Climate change signals of the indices for the near future (NF, 2021-2050) and the far future (FF, 2071-2100) for the whole year, the summer half-year and winter half-year (SHY, WHY) for four elevation levels (Lowlands, Hillsides, Mountains, Ridges; see Table 2); for units see Table 1; red and blue indicate positive and negative trends, respectively 

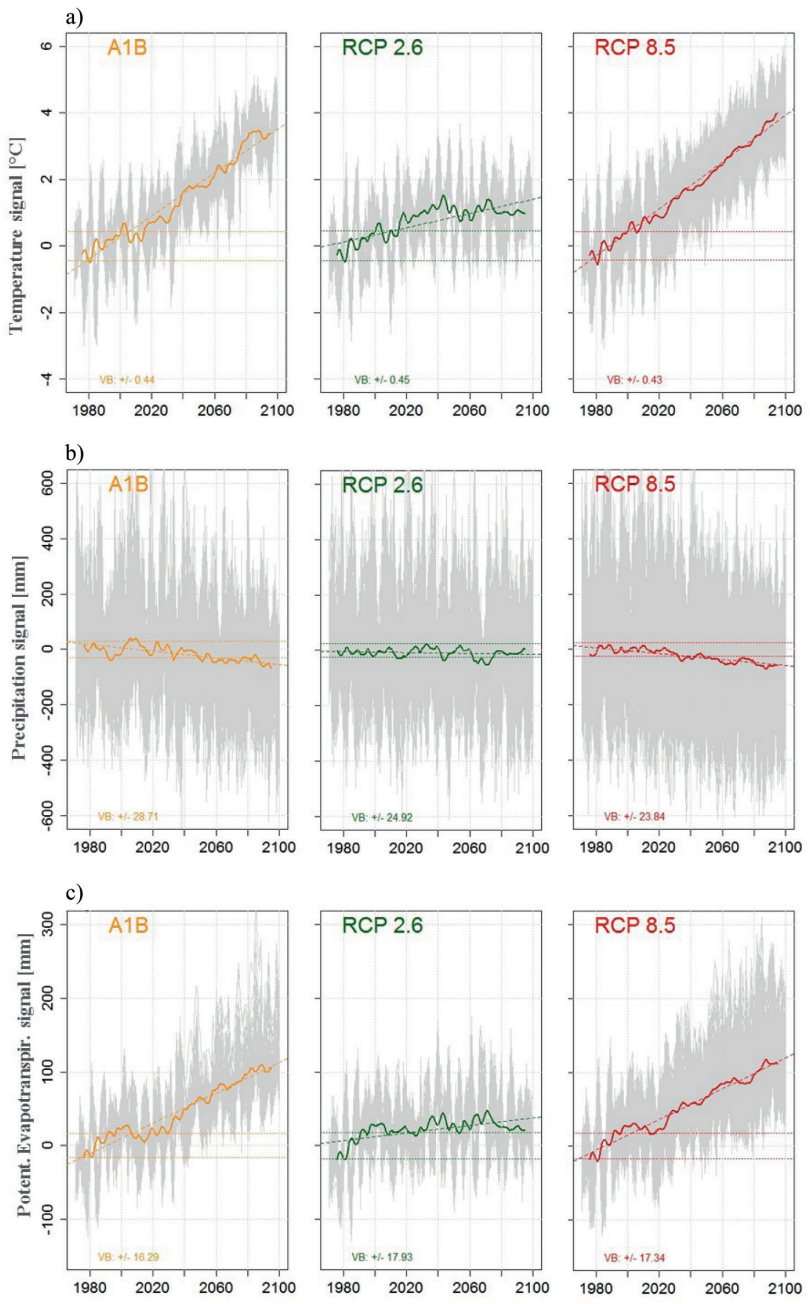

Fig. 5. Climate change signals of (a) mean temperature, (b) precipitation and (c) potential evapotranspiration of the period 1971-2100. Grey: results of all ten WETTREG2013 realizations of EH5-A1B and MPI-ESM-LR, RCP 2.6 as well as all 30 realizations of MPI-ESM-LR, RCP 8.5. Thick coloured line: mean smoothed realization; dashed coloured line: trend line of the period 2010-2100; dotted coloured line: confidence interval of the mean realization

perature and sunshine duration - more affected by increases in ETP. This is due to the non-linearity of changes at different temperature and radiation levels. For example, a change in the mean yearly temperature in the Lowlands $\left(9^{\circ} \mathrm{C}\right)$ of about $1^{\circ} \mathrm{C}$ causes a different signal in ETP than a change of about $1^{\circ} \mathrm{C}$ at the Ridges, where the annual mean is $3.6^{\circ} \mathrm{C}$. Changes in the SHY are much higher than in the WHY due to similar changes in sunshine duration.

The Climatic Water Balance decreases significantly in the SHY - only slightly for RCP 2.6, but strongly for A1B and RCP 8.5. The changes in the NF are still moderate, but they aren't in the FF. During the WHY, changes in the CWB are negligible; in lower elevated regions, even increased CWB signals are found. Higher elevated regions show the highest losses in their climatic water availability, which are caused by significant precipitation deficits. Fig-

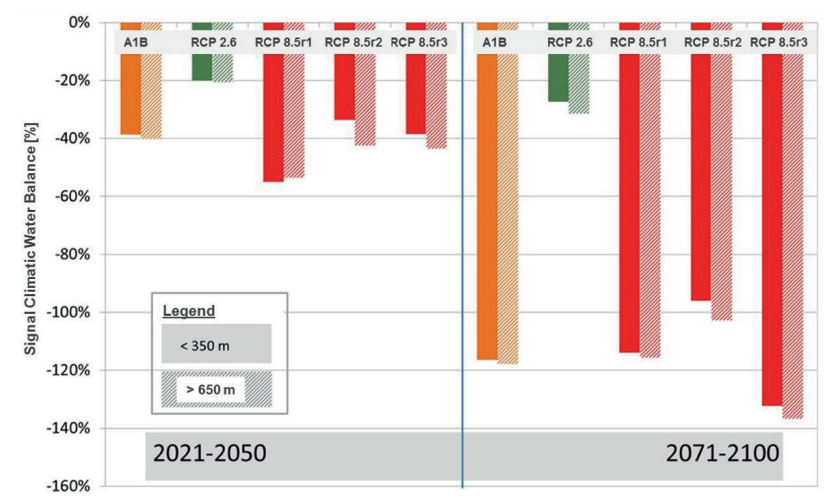

Fig. 6. Projected relative signal of the Climatic Water Balance of the summer half-year for the near and far future and two elevation levels. The colours resemble those of Fig. 5

ure 6 focuses on the CWB changes during the SHY. Relative changes are displayed, i.e. the absolute projected changes in relation to simulated CWB of 1971-2000. The changes in the NF are between $-20 \%$ and $-55 \%$, but they are markedly higher in the FF (between $-30 \%$ and $-135 \%$ ). The relative differences between the two displayed elevation levels are not as pronounced as the absolute differences in Table 4. The Ridges have an abundant precipitation input and a clearly positive CWB. Absolute reductions of up to $178 \mathrm{~mm}$ (RCP 8.5 for the FF) are therefore in relative terms less dramatic. A part of the uncertainty of climate modelling can be determined by the comparison of the three model runs of RCP 8.5 (Fig. 6). Only (accidental) change in the initial conditions of the GCM leads to quite different climatic values, and hence water availability. The uncertainty within RCP 8.5 is higher than its difference, when compared to A1B.

\section{Discussion}

The location of the investigation area within a climatological transition zone causes - in comparison to the neighbouring German state of Saxony - generally lower precipitation totals and increased sunshine duration. Because Saxony and the investigation area overlap, no exact quantification of the difference is possible based on the performed analysis. However, the region concerned is very variable and some parts are very specific. For example, sunshine duration might be lower in the Isera Mountains than in Saxony, while precipitation might be higher if compared to stations of similar altitude. There exist strong vertical gradients, so the Lowlands are warmer, drier and have more sun hours than higher regions. During the investigated period, the climate changed. Significant increases were found for temperature, sunshine duration and potential evapotranspiration for many stations. Negative tendencies were found for precipitation in the SHY, in con- 
trast to the WHY. It is of note that trends are sensitive to the length of the period and extreme values lying at the beginning or end of the series. To show an example of this, the precipitation time series of the station Görlitz for the period 1903-2013 was analysed. The relative trends for the periods $1903-2013,1961-1990$, and $1971-2010$ are $7.5 \%$, $3.4 \%$ and $0.9 \%$, respectively. One should be aware of this problem when analysing trends.

A further aspect that was mentioned by Lünich et al. (2014a) is that observed precipitation trends point to a higher variability in summer, with more heavy precipitation events and - at the same time - more and longer lasting dry periods of at least 11 days. This could lead to more frequent erosion events, which implies soil loss and matter transport into water bodies. For the future, no clear behaviour referring to this was found. Further investigation, which focuses on such extremes, could clarify this question.

The CWB, as an indicator for water availability, shows that water stress - from a climatological point of view increases in the SHY but decreases in the WHY. The reason is the increased ETP throughout the whole year. Only, in the WHY the positive trends of precipitation exceed the increases in ETP. CWB deficits are, to a small extent, compensated for in the WHY. Especially critical here is the situation in the Lowlands, because it evaporates (potentially) more than it rains on an annual basis. Similar results were found at the Polish/Ukrainian border (Fischer et al. 2014; Pavlik et al. 2014).

A small ensemble of emission scenarios/concentration pathways, driving models and model runs was applied to investigate the bandwidth of possible future climate characteristics. Scenario A1B was used as a reference to many studies of the past, like precipitation projections for Central Eastern Germany (Schwarzak et al. 2014). The RCP 2.6 is recently considered as the lower limit of climate changes, which can be achieved only with enormous effort to reduce greenhouse gas emissions. The RCP 8.5 is currently the most probable scenario, because greenhouse gas emissions of recent years coincide with this scenario.

Climate changes are not grave for many climatic variables for the near future (2021-2050), i.e. they didn't leave the range of natural variability. But for the far future (2071-2100), significant increases of the mean yearly temperature $\left(1.0-3.6^{\circ} \mathrm{C}\right)$, of precipitation during the WHY (4-26 mm), of yearly sunshine duration (44-345 hours) and yearly potential evapotranspiration (23-108 $\mathrm{mm}$ ) are projected. Only precipitation during the SHY (from 3 to $-116 \mathrm{~mm}$ ) and yearly climatic water balance decreases (from -16 to $-203 \mathrm{~mm}$ ).

A direct comparison of our results with other investigations is difficult, due to different reference or investigation periods. The mean yearly temperature signal (A1B, 20712100 ) of this study is $3.5^{\circ} \mathrm{C}$, in comparison to $3-3.5^{\circ} \mathrm{C}$ from the ENSEMBLES project (van der Linden, Mitchell 2009; Schwarzak et al. 2014), which used the reference period 1961-1990. The precipitation signal of this study for SHY is $-15 \%$ and for ENSEMBLES 5-15\% in spring and -15 to $5 \%$ in summer. Our RCP 2.6 and 8.5 projection results for mean temperature coincide well with IPCC (2013) (they compared 2081-2100 versus 1986-2005), but are much drier than IPCC. This indicates that the WETTREG2013 projections are drier than other models and leads to the following: we cannot conclude from our ensemble the possible bandwidth of the development of climatic conditions. Other GCM with more extreme temperature and precipitation behaviour could not be considered as a driving model for WETTREG2013, because it is not possible to process extremes that haven't been observed yet. WETTREG2013 projections for the future are based on statistical relationships between observed weather patterns and climate observations at the stations. No new extremes in the future can be generated. From a scientific point of view, it is not possible to reject GCM simulations with pronounced extremes, if these models otherwise perform well. Therefore, our study only provides a first impression of the possible bandwidth of climatic development in the Polish-Saxon border region.

Applying two water balance models, the hydrologic response of the Lusatian Neisse catchment on the projected climatic forcing was investigated in the project NEYMO (Lünich et al. 2014b). Results are summed up as follows: The actual evapotranspiration increased in the past 40 years and will increase slightly in the future. During the SHY the future actual evapotranspiration will decrease due to limited water availability (although potential evapotranspiration will continue increasing). Surface runoff increased in the past, but will decrease until the end of the $21^{\text {st }}$ century. Groundwater recharge increased on an annual basis but significantly decreased in the SHY in the past. For the future, a strong decrease in the SHY and a moderate decrease in the WHY are projected. Reduced precipitation, higher temperature and solar radiation indeed lead to the expected hydrologic response.

\section{Conclusions}

The changes of climatic variables caused a reduced water availability in the summer half-year in the past 40 years, and climate projections until 2100 point in the same direction. Water deficits in the SHY were partly compensated for during the WHY in the past. This compensation will vanish in the future. 
These changes can impact many socio-economic sectors, e.g. water management and agriculture. Reduced water availability during the SHY can impede agricultural production, although a longer vegetation period and higher carbon dioxide concentrations can also have positive effects. As well as this, very probable effects are reduced river discharges and groundwater tables (Lünich et al. 2014b).

\section{Acknowledgment}

The projects NEYMO and KLAPS were funded by the European Fund for Regional Development (EFRE). The implementation took place in the framework of the operational program Ziel 3, which promotes the transnational cooperation between Poland and the German State Saxony. Many thanks to the two anonymous reviewers and the very detailed language check, which helped to improve the manuscript.

\section{Bibliography}

Ångström A., 1924, Solar and terrestrial radiation. Report to the international commission for solar research on actinometric investigations of solar and atmospheric radiation, Quarterly Journal of Royal Meteorological Society, 50 (210), 121-126, DOI: $10.1002 /$ qj. 49705021008

ATV-DVWK, 1996, Ermittlung der Verdunstung von Land- und Wasserflächen. Deutsche Vereinigung für Wasserwirtschaft, Abwasser und Abfall e.V., Merkblatt M 238, Bonn, 135 pp.

Bernhofer C., Franke J. (eds.), 2013, Aufbereitung meteorologischer Daten für die Verwendung im Klimamodell im Rahmen des Projektes NEYMO. Final Report, LfULG, Dresden, $42 \mathrm{pp}$.

Fischer S., Pluntke T., Pavlik D., Bernhofer C., 2014, Hydrologic effects of climate change in a sub-basin of the Western Bug River, Western Ukraine, Environmental Earth Sciences, 72 (12), 4727-4744 DOI: 10.1007/s12665-014-3256-Z

Głowicki B., Otop I., Urban G., Tomczyński K., 2005, Climate (in Polish), [in:] Opracowanie Ekofizjograficzne dla Województwa Dolnośląskiego, WBU, Wrocław, 53-62

IPCC, 2013, Climate Change 2013: The Physical Science Basis. Contribution of Working Group I to the Fifth Assessment Report of the Intergovernmental Panel on Climate Change, T.F. Stocker, D. Qin, G.-K. Plattner, M. Tignor, S.K. Allen, J. Boschung, A. Nauels, Y. Xia, V. Bex, P.M. Midgley (eds.), Cambridge University Press, Cambridge, United Kingdom and New York, NY, USA, 1535 pp.

Jacob D., 2007, An intercomparison of regional climate models for Europe: model performance in present-day climate, Climate Change, 81 (1), 31-52, 10.1007/s10584-006-9213-4

Kendall M.G., 1976, Rank Correlation Methods, $4^{\text {th }}$ edition, Charles Griffin, London, UK
Kreienkamp F., Spekat A., Enke W. (eds.), 2013, Climate projections for the project KLAPS), Publication of the EU-Project KLAPS, LfULG, Dresden, 35 pp.

Lünich K., Pluntke T., Niemand C., Adynkiewicz-Piragas M., Zdralewicz I., Otop I., Miszuk B., Kryza J., Lejcuś I., Strońska M., 2014a, Lausitzer Neiße - Charakteristik und Klima der Region, Publication of the EU-Projektes Lausitzer Neiße/Nysa Łużycka - Klimatische und hydrologische Modellierung, Analyse und Prognose, Dresden, 69 pp.

Lünich K. Prasser M., Niemand C., Adynkiewicz-Piragas M., Zdralewicz I., Otop I., Miszuk B., Kryza J., Lejcuś I., Strońska M., 2014b, Lausitzer Neiße - Wasserressourcen in der Region, Publication of the EU-Project Lausitzer Neiße/ Nysa Łużycka - Klimatische und hydrologische Modellierung, Analyse und Prognose, Dresden, 138 pp.

Mann H.B., 1945, Nonparametric tests against trend, Econometrica, 13 (3), 245-259, DOI: 10.2307/1907187

Mehler S., Völlings A., Flügel I., Szymanowski M., Błaś M., Sobik M., Migała K., Małgorzata W., Kryza M., Miszuk B., Otop I., Kolanek A., Strońska M., 2014, Das Klima in der Polnisch-Sächsischen Grenzregion, Publication of the EUProject KLAPS - Klimawandel, Luftverschmutzung und Belastungsgrenzen von Ökosystemen im polnisch-sächsischen Grenzraum, Dresden, 80 pp.

Nakicenovic N., Swart R., 2000, Special Report on Emissions Scenarios, A Special Report of Working Group III of IPCC, Cambridge University Press, Cambridge, UK

Pavlik D., Söhl D., Pluntke T., Bernhofer C., 2014, Climate change in the Western Bug river basin and the impact on future hydro-climatic conditions, Environmental Earth Sciences, 72 (12), 4787-4800, DOI: 10.1007/s12665-014-3068-1

Randalls S., 2010, History of the $2^{\circ} \mathrm{C}$ climate target, Wiley Interdisciplinary Reviews: Climate Change, 1 (4), 598-606. DOI: $10.1002 /$ wcc. 62

Schwarzak S., Hänsel S., Matschullat J., 2014, Projected changes in extreme precipitation characteristics in Central Eastern Germany $\left(21^{\text {st }}\right.$ century, model-based analysis), International Journal of Climatology, 35, 2724-2734, DOI: 10.1002/ joc. 4166

SMUL, 2005, Climate change in Saxony. Current situation and outlook, Dresden, (in German), 111 pp.

Taubenheim J., 1969, Statistical analysis of geophysical and meteorological data, Leipzig: Akademische Verlagsgesellschaft Geest \& Portig K.-G

Van der Linden P., Mitchell J.F.B., 2009, ENSEMBLES: Climate Change and its Impacts: Summary of research and results from the ENSEMBLES project, Met Office Hadley Centre, FitzRoy Road, Exeter EX1 3PB, UK

VDI, 1994, Environmental Meteorology. Interactions between Atmosphere and Surfaces. Calculation of Short-wave and Long-wave Radiation, VDI 3789 